\title{
FOUR SPECIES OF SAXICOLOUS LICHENIZED FUNGI NEW TO LATVIA
}

\author{
Rolands Moisejevs ${ }^{1 *}$, Polina Degtjarenko² \\ ${ }^{1}$ Institute of Life Sciences and Technology, Daugavpils University, Parādes Str. 1a, Daugavpils LV-5401, Latvia \\ ${ }^{2}$ Institute of Ecology and Earth Sciences, University of Tartu, Lai Str. 38, Tartu EE-51005, Estonia \\ * Corresponding author. E-mail: rolands.moisejevs@biology.lv
}

\begin{abstract}
Moisejevs R., Degtjarenko P., 2017: Four species of saxicolous lichenized fungi new to Latvia [Keturios epilitinių kerpių rūšys naujos Latvijai]. - Bot. Lith., 23(1): 60-62.

Four species of saxicolous and acidophilous lichens - Dermatocarpon miniatum, Trapelia coarctata, Trapelia placodioides, and Umbilicaria hirsuta found on different types of granite boulders were reported as new to Latvian lichen biota. Data on substratum geology, accompanying species, microhabitat and distribution in neighbouring to Latvia countries are provided.
\end{abstract}

Keywords: acidophilous, epilithic, lichens.

In recent years, knowledge about lichens and allied fungi in Latvia has significantly increased (Piterāns, 2001; Āboliña et al., 2015; Motiejūnaité et al., 2016). Nevertheless, the saxicolous lichens still remain one of the least studied lichenized fungi group in the Baltics (ĀBOLIN̦A et al., 2015; MotieJŪNAITE et al., 2016). The current paper complements the knowledge about Latvian biota of lichenized fungi. Four species of saxicolous lichenized fungi were reported as new to Latvia. The species were found in 2016-2017, on rapakivi granite boulders in different regions of Latvia. All of these boulders have probably been transported to Latvia from the southwestern part of Finland during the last glaciation, i.e. Weichselian glaciation (ZeLČs \& MARKOTS, 2004).

The collections were determined using the routine lichenological methods (SMITH et al., 2009). Spot-test reactions were checked with $10 \% \mathrm{KOH}(\mathrm{K})$, sodium hypochlorite $(\mathrm{C})$, para-phenylenediamine in ethanol (Pd), and Lugol's solution (I). The nomenclature of taxa follows Nordin et al. (2011). Doubtful specimens were compared to the collections deposited at the Herbarium of the Institute of Botany, Nature Research Centre, Vilnius (BILAS). The description of substrata and list of accompanying lichen species is provided. The data on species distribution in neighbouring countries is also provided, except Pskov region for Russia, due to unconfirmed occurrence of all referred species in the region (Irina Stepanchikova, pers.comm). All collected specimens were deposited at the Herbarium of Daugavpils University, Institute of Life Sciences and Technology (DAU).

\section{LIST OF SPECIES:}

\section{Dermatocarpon miniatum (L.) W.Mann.}

The lichen inhabited well-lit surface of boulder top, on south-facing part. The accompanying species were: Acarospora fuscata, Aspicilia cinerea, Protoparmeliopsis muralis, Rhizocarpon geminatum, Phaeophyscia nigricans, Phaeophyscia sciastra, and Xanthoparmelia conspersa. Dermatocarpon miniatum is known in Belarus (TSURYKAU \& KHRAMCHANKova, 2011) and Estonia (RANDlANE et al., 1999). So far, this species is only known from literature data in Lithuania (MotıesūNAITÉ, 1999). D. miniatum is included into the Red Data Book of the Republic of Belarus (KHORUZHIK, 2005). 
Specimen examined: Ogres Co., Lauberes Distr., $200 \mathrm{~m}$ to the west of Ančinuu House, Ančinu devil's stone; on the upper surface of exposed granite boulder, rapakivi granite with multiple cracks. Metamorphic rock - coarse-grained gneiss (metamorphosed granite) with dominance of orthoclase feldspars. Leg. et det. Rolands Moisejevs, 24 April 2017; $56^{\circ} 50^{\prime} 36.3^{\prime \prime} \mathrm{N}, 25^{\circ} 03^{\prime} 07.1^{\prime \prime}$ E. Ančinu devil's stone; DAU (438002001).

\section{Trapelia coarctata (Sm.) M.Choisy}

The lichen was found on the north-east-facing side of the boulder, on the bottom and central part. The microhabitat can be characterized as shaded with scabrous surface. The accompanying species were: Candelariella aurella, Porpidia crustulata, Porpidia macrocarpa, Rhizocarpon geminatum, and Trapelia placodioides. Trapelia coarctata is known in Lithuania (MotieJūNAITE, 1999), Belarus (TsuRYKAU \& Khramchankova, 2011), and Estonia (RANDlane et al., 1999).

Specimen examined: Daugavpils Co., Nīcgales Distr., protected landscape area "Nīcgales meži", included into NATURA 2000 protected territory net, 6 $\mathrm{km}$ to the east of railway station, Nicgale Big White Stone; on a well-lit granite boulder; rapakivi granite. Intrusive igneous rock - coarse-grained granite with porfiric texture. Felsic rock with dominance of plagioclase feldspars. Leg. Rolands Moisejevs, $12 \mathrm{Au}-$ gust 2016; 56 09'07.9” N, 26²7'41.9” E. Det. Jurga Motiejūnaite, 27 August 2016; DAU (546001001).

\section{Trapelia placodioides Coppins \& P.James}

The lichen grew on the north-east-facing side of the boulder, on the bottom and central part. The microhabitat can be characterized as shaded with scabrous surface. The accompanying species were: Candelariella aurella, Porpidia crustulata, Porpidia macrocarpa, Rhizocarpon geminatum, and Trapelia coarctata. Trapelia placodioides is known in Lithuania (MotiesūNAITÉ, 1999) and Estonia (RANDLANE et al., 1999).

Specimen examined: Daugavpils Co., Nīcgales Distr., protected landscape area "Nīcgales meži", included into NATURA 2000 protected territory net, $6 \mathrm{~km}$ to the east of railway station, Nicgale Big White Stone; on a granite boulder; rapakivi granite. Intrusive igneous rock - coarse-grained granite with porfiric texture. Felsic rock with dominance of plagioclase feldspars. Leg. et det. Rolands Moisejevs, 12 August 2016; 56 09'07.9” N, 26²7'41.9” E. DAU (546002001).

\section{Umbilicaria hirsuta (Sw. ex Westr.) Hoffm.}

The species was found on the top and east-facing part of boulder surface. The surface of boulder can be described as scabrous with numerous cracks. The accompanying species were: Acarospora fuscata, Aspicilia cinerea, Candelariella aurella, Protoparmeliopsis muralis, and Xanthoparmelia conspersa. U. hirsuta has so far been reported only from Estonia, where it has recently been recorded in the northern part of the country (RANDLANE et al., 2014).

Specimen examined: Ventspils Co., Ugāles Distr., $100 \mathrm{~m}$ to the south of the Māteri Cemetery. The Devil's Foot Stone in Mâteri is located on top of a Liepkalns Hill, in a clear meadow; on well-lit horizontal surface of a granite boulder; rapakivi granite. Intrusive igneous rock - coarse-grained granite. Felsic rock with dominance of orthoclase feldspars. Leg. Rolands Moisejevs, 12 February 2017; 57¹4’35” N, $21^{\circ} 57^{\prime} 47^{\prime}$ 'E. Det. Polina Degtjarenko, 13 February 2017; DAU (635003001).

\section{ACKNOWLEDGEMENTS}

The authors are grateful to Jurga Motiejūnaite (Nature Research Centre, Vilnius) for checking the determination of doubtful specimens. Juris Soms (Daugavpils University) is also thanked for providing geological data. Irina Stepanchikova (St. Petersburg State University \& Komarov Botanical Institute, Russian Academy of Sciences) and Andrei Tsurykau (Gomel State University) are thanked for sharing the information about species distribution in Russia (Pskov region) and Belarus.

\section{REFERENCES}

ĀBoliṇa A., Piterāns A., Bambe B., 2015: Lichens and bryophytes in Latvia. Checklist. - Salaspils.

KHORUZHIK L.I., 2005: Red data book of the Republic of Belarus: Rare and endangered species of wild plants. - Minsk.

MotieJūNAitė J., 1999: Checklist of lichens and allied 
fungi of Lithuania. - Botanica Lithuanica, 5(3): 251-269.

Motiejūnaité J., Chesnokov S.V., Czarnota P., Gagarina L.V., Frolov I., Himelbrant D., Konoreva L.A., Kubiak D., Kukwa M., Moisejevs R., Stepanchikova I., Suija A., Tagirdzhanova G., Thell A., Tsurykau A., 2016: Ninety-one species of lichens and allied fungi new to Latvia with a list of additional records from Kurzeme. Herzogia, 29(1): 143-163.

Nordin A., Moberg R., Tønsberg T., Vitikainen O., Dalsätt Å., Myrdal M., Snitting D., Ekman S., 2011: Santesson's Checklist of Fennoscandian Lichen-forming and Lichenicolous Fungi. Uppsala.http://130.238.83.220/santesson/home.php [April 29, 2011].

Piterāns A., 2001: Checklist of the lichens of Latvia. - Latvijas veǵetācija, 3: 5-46.

Randlane T., Lõhmus P., Martin L., Suija A., 2014:

New Estonian records and amendments: Lichen- ized and lichenicolous fungi. - Folia Cryptogamica Estonica, 51: 135.

Randlane T., SaAg A., 1999: Second checklist of lichenized, lichenicolous and allied fungi of Estonia. - Folia Cryptogamica Estonica, 35: 1-132.

Randlane T., SAag A., Suija A., 2016: Lichenized, lichenicolous and allied fungi of Estonia. Ver. December 31, 2016. http://esamba.bo.bg.ut.ee/ checklist/est/home.php.

Smith C.W., Aptroot A., Coppins B.J., Fletcher A., Gilbert O.L., James P.W., Wolseley P.A., 2009: The lichens of Great Britain and Ireland. - London.

Tsurykau A., Khramchankova V., 2011: Lichens from Gomel region: a provisional checklist. - Botanica Lithuanica, 17(4): 157-163.

ZelČs V., Markots A., 2004: Deglaciation history of Latvia. - In: Ehlers J., GibBard P.L. (eds), Quaternary Glaciations - Extent and Chronology. Riga.

\section{KETURIOS EPILITINIŲ KERPIŲ RŪŠYS NAUJOS LATVIJAI}

\section{Rolands Moisejevs, Polina Degtjarenko}

\section{Santrauka}

Keturios epilitinès acidofilinès kerpių rūšys Dermatocarpon miniatum, Trapelia coarctata, Trapelia placodioides ir Umbilicaria hirsuta aptiktos ant įvairių granito riedulių buvo rastos pirmą kartą
Latvijoje. Straipsnyje pateikiami duomenys apie jų substrato geologiją, mikrobuveinès savybes ir rūšių paplitimą aplinkinèse šalyse. 